\title{
Transformation of urban brownfields through co-creation: the multi-functional Lene-Voigt Park in Leipzig as a case in point
}

Nadja Kabisch ${ }^{1,2}$

Correspondence: nadja.kabisch@ geo.hu-berlin.de

'Department of Geography, Humboldt-Universität zu Berlin, Unter den Linden 6, 10099 Berlin, Germany

${ }^{2}$ Helmholtz Centre for Environmental Research - UFZ, Department of Urban and Environmental Sociology, Permoserstraße 15, 04318 Leipzig, Germany

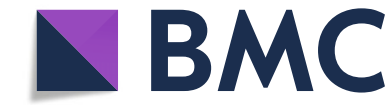

\section{Policy and practice recommendations}

- Include different age groups such as children and elderly in the co-creation of a brownfield transformation project.

- Create diverse opportunities for appropriation to strengthen broad acceptance and use of public green spaces.

- Consider all potential barriers to green space use such as safety concerns. Be flexible to adapt maintenance strategies.

- Incorporate a temporal scale in the co-creation process taking into account past and future demographic and urban development.

(c) The Author(s). 2019 Open Access This article is distributed under the terms of the Creative Commons Attribution 4.0 International License (http://creativecommons.org/licenses/by/4.0/), which permits unrestricted use, distribution, and reproduction in any medium, provided you give appropriate credit to the original author(s) and the source, provide a link to the Creative Commons license, and indicate if changes were made. The Creative Commons Public Domain Dedication waiver (http://creativecommons.org/ publicdomain/zero/1.0/) applies to the data made available in this article, unless otherwise stated. 


\section{Introduction}

Cities worldwide face multifaceted and complex challenges related to climate change and urbanisation, including environmental pollution, social exclusion, heat waves, traffic congestion and the lack of green spaces that are directly linked to a broad range of health and well-being outcomes (United Nations - Department of Economic and Social Affairs 2018; Intergovernmental Panel on Climate Change 2018; European Environment Agency 2018). The intersection of health and well-being, environment and public green spaces has gained prominence through the Sustainable Development Goals (SDGs) and the New Urban Agenda (NUA). These call on cities to become protagonists in ensuring sustainability by rethinking the way we design and live in urban areas. In particular, they demand capacity and actions aiming at transformations to urban sustainability (Wolfram et al. 2019).

For some decades now, policy makers and urban planners have been trying to implement distinct measures to increase sustainable development and improve the quality of life in cities (Kabisch et al. 2017a; De Sousa 2003) through the development and implementation of green spaces such as urban public parks. These may provide a multitude of ecosystem services to people such as cooling the air through shading and evapotranspiration (Ziter et al. 2019; Bowler et al. 2010), improving air quality through filtering pollutants (Nowak et al. 2006) reducing noise perception (Dzhambov and Dimitrova 2015) and providing recreational opportunities such as space and an atmosphere to relax, enjoy, learn from nature or do some sports. They also enable people to be more physically active, to improve their motor skills, to be outside and provide opportunities for social connectedness and to link nature across different socioeconomic, cultural and demographic backgrounds (McCormack et al. 2014; Kabisch et al. 2015; Fischer et al. 2018). The use of parks for physical activity and social interaction has particularly proven to have important benefits for both health and wellbeing through multiple pathways (Hartig et al. 2014; McCormack et al. 2010) and in particular for vulnerable groups such as children and the elderly (Kabisch et al. 2017b; Wolch et al. 2011).

Although the benefits of urban green spaces are profound, the implementation of urban green, e.g. through the development of new public parks is challenging in growing cities as space is contested and cities are under pressure to provide sufficient residential space for the increasing number of inhabitants, while maintaining and improving the sustainability and quality of life. The transformation of urban brownfield sites into multifunctional green spaces and parks may be one option to increase green spaces in a growing city.

\section{Participation in brownfield regeneration projects}

A number of cities including large North-American cities of the Rust Belt and in Canada, in Japan, the British Midlands in the UK, or the Ruhr area in western Germany and major parts of eastern Germany such as the cities of Berlin or Leipzig experienced declining population numbers decades ago, but are now re-growing extensively (Rall and Haase 2011; Wolff et al. 2017; Kabisch and Haase 2011). These cities often have neglected inner city spaces such as industrial or railway brownfield sites. In fact, derelict brownfield sites have been the focus of comprehensive urban regeneration projects 
all over the globe (for a comprehensive definition of urban regeneration see Balaban and Puppim de Oliveira 2014) to improve environmental conditions in cities through the increase in urban green spaces. Such urban regeneration projects have been accompanied more and more by intensive participation processes. For example, in Berlin the inner city transformations of the former airport Berlin-Tempelhof and the former railway brownfield -"Gleisdreieck" - into public parks were accompanied by intensive participation processes including public discussion forums, workshops, surveys and focus group discussions where people from the local neighbourhoods could actively get involved in the process, argue for their particular needs and desires and were therefore involved in co-designing the area (Frantzeskaki and Kabisch 2016b; Kabisch 2015).

In Toronto, Canada, local urban experiences highlighted that the redevelopment of brownfield sites has led to a substantial increase in urban green spaces with multiple benefits such as an increase in biodiversity and recreational spaces, but has required an extensive involvement of multiple stakeholders from the public-sector, community and neighbourhood groups, decision makers and city planners from all affected departments in an open and transparent discussion and involvement process (De Sousa 2003). In London, the UK, the Barking Riverside brownfield was redeveloped, recognising the importance of the habitat function in addition to the value of many other ecosystem services, including water regulation for stormwater storage and the provision of recreational space (Connop et al. 2016). The many sustainability objectives were addressed comprehensively through a knowledge transfer partnership of key stakeholders that included partners from research, development agencies, local authorities, local communities and small and medium sized enterprises (SMEs). Even a Community of Interest Company of local residents was established to ultimately take over management and maintenance responsibilities. In Kanzwana City, a mid-sized town in Japan, an urban regeneration project that focussed on the redevelopment of vacant land included climate-friendly strategies to increase the provision of green spaces in the inner city area (Balaban and Puppim de Oliveira 2014). Green and blue space was increased by uncovering previously covered water canals to develop them as public green walkways in addition to the establishment of a new park. Green space was significantly increased in the city, which is important for the provision of climate-regulating ecosystem services as such green spaces enable wind circulation and increase cooling through evaporation. In terms of participation, the advisory body for the regeneration plan of Kanzwana contained members from different public and private organisations, while a questionnaire survey with local residents was also carried out with the main aims of increasing understanding of the context situation in the urban area and of defining expectations and desires from the plan. The questionnaire survey increased transparency, raised awareness of the plan and enabled community participation in the decision-making process (ibid).

The importance of an intensive participation process including a diverse range of local stakeholders for successful regeneration projects is impressively shown by (Mancebo 2014). In the case of Seine-Saint Denise in the Paris region, the implementation of new parks to provide ecosystem services to mitigate challenges from severe industrial environmental conditions and to offer huge recreational spaces finally had no effect on the attractiveness and the use of the area by local residents (Mancebo 2014). Parks there were created top-down without involving the local communities in the 
implementation and design process. As a result, local community groups and residents of the neighborhoods did not use the parks because they had the feeling that the new parks did not belong to their lives as they had no stake in their design and implementation.

\section{Aims and approach}

In this paper, the transformation of an urban brownfield into a public park in the formerly declining and now re-growing city of Leipzig, Germany is introduced. More than 15 years after the Lene-Voigt Park was established, it illustrates that the transformation of a former urban brownfield site into a multifunctional urban park was successful in providing multiple benefits precisely because of the co-creation approach adopted, involving multiple stakeholder in the planning process. It will also discuss how the local context of urban structure and demographic development may act as a physical and mental barrier in the realisation of all co-produced ideas into practice and show the challenges that the park is facing today. These challenges are linked to challenges related to climate change and urbanisation - namely heat waves and population increases. Recommendations are finally derived to trigger new exchanges on emerging and future cases, enable comparisons and inspire wider discussions.

The arguments provided in this article are based on methodological triangulation. Primary data was collected through semi-structured interviews with responsible coordinators of the regeneration project from urban governmental institutions and representatives of academia that were involved in the participation process. Primary data collection was complemented by multiple site visits in different seasons between March 2018 and April 2019 and a seven-day project field campaign in July 2018 in which the total park area was assessed by structured visitor observations as part of an empirical social science based study in the GreenEquityHealth project (Kabisch 2018). Furthermore, secondary data was gathered through in-depth literature analysis of policy documents, research articles, project documentation material and media articles.

\section{Case study: City of Leipzig, Germany and the Lene-Voigt Park}

Urban development in the city of Leipzig

The city of Leipzig is a compact eastern German city located in the Federal State of Saxony. The population of the city experienced decades of growth and decline in the 20th century until now with a peak population of around 700,000 inhabitants in the early 1930s. The city faced severe population decline after the German reunification in 1989 due to tremendous societal transition with de-industrialisation coupled with massive unemployment and out-migration to the western parts of the country. Population numbers decreased by nearly a fifth with 530,000 inhabitants in 1989 falling to 437,000 inhabitants in 1998 (Wolff et al. 2017). Ongoing de-industrialisation and massive demolition programmes of vacant houses during the 1990s produced new spatial patterns such as urban structures with brownfield sites, demolition corridors and 'housing islands'. Urban brownfield sites accounted for up to approximately $3.5 \%$ of the city area in 2015 (City of Leipzig 2015a). Since 2002 the population has been steadily increasing with a total number of around 598,000 in 2018 . The city population prognosis suggests an increase to almost 722,000 inhabitants by 2032 (City of Leipzig 
2015b). Accordingly, vacancy rates have decreased and residential development processes in the form of new investments with increasing rent are taking place in almost every available spot in attractive city areas (Wolff et al. 2017). However, Leipzig is still considered to be a green city with $17.89 \%$ of its total area of $297.38 \mathrm{~km}^{2}$ comprising of urban forests, cemeteries, allotment gardens, urban parks and other recreational areas in 2017 (City of Leipzig 2018a). Green spaces even increased due to urban green development projects. The redevelopment of the "Eilenburger Bahnhof" - a railway brownfield into a new inner city park - named Lene-Voigt Park is one example where derelict inner-city transportation areas have been converted into a new urban green space. The park was named after Lene Voigt (1891-1962) - a German poet from Leipzig.

\section{The Lene-Voigt Park urban transformation project}

The park is located in the eastern part of the city in a dense compact residential area with housing stock mainly from the Wilhelminian period (Fig. 1, (Banzhaf et al. 2018)). The total park size is $11 \mathrm{ha}$. It is constructed as a rectangular park with a length from the western to eastern entrance of $800 \mathrm{~m}$. The former railway site was called "Eilenburger Bahnhof" and was constructed back in 1874 and used until the 1960s/70s (City of Leipzig 2018b). The area was left abandoned until 2000. As part of the citywide Urban Development Plan for Residential Development and Urban Regeneration (STEP W + S) and the District Plan Leipzig East, the city finally decided to develop the park for creating more recreational space in quantity, improving the social and environmental conditions in the very dense less green eastern part of Leipzig, developing a fresh air corridor; and creating areas for cyclists to be able to connect to the cycling network of the city (City of Leipzig 2005).

After intensive conversations with local property owners at the end of the 1990s, the city of Leipzig started to purchase adjacent areas that had not previously been owned by the city. In addition, the city initiated a landscape architect competition to create

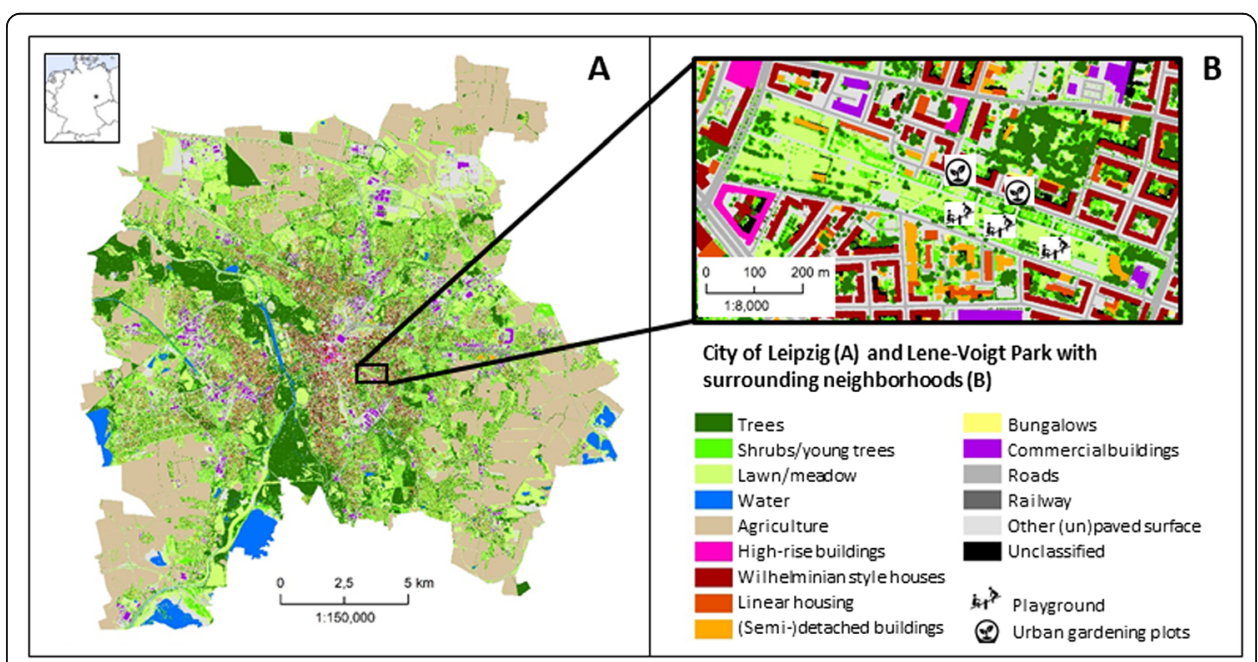

Fig. 1 Landuse and Landcover (LULC) of the city of Leipzig (a) and location of the Lene-Voigt Park in the city (b, LULC data based on Banzhaf and Kollai (2018) 
design scenarios for the brownfield site in 1998. Landscape architects from Berlin were successful and initiated a co-creation process together with the city of Leipzig in the early years of the new Millennium (Costa and Mathey 2007). The co-creation process involved local residents, community groups, and practitioners (including urban planners from the City departments responsible for urban and green development; and planners and designers working in the landscape design office). International researchers accompanied the process and helped in the coordination of participation formats. The work of international researches was part of the EU 5th framework research project URGE (Development of Urban Green Spaces to Improve the Quality of Life in Cities and Urban Regions) in which Leipzig was a case study. The participation formats included local workshops, focus group discussions, site visits, children camps and an international planning seminar, in which stakeholders and actors could openly present and discuss their needs and desires (ibid). A main aim was to address the needs of different age groups such as children and youths and very local communities and to give them a chance to communicate their views and expectations about a new park.

The final design of the park, therefore, includes different areas dedicated to the requirements of different users and age groups: main lawn areas for recreational purposes (silent areas), sports areas and playgrounds (active areas) and side lots for urban gardening activities. It was the first time in the city of Leipzig, that inner park areas were made available for individual or community gardening activities and a new approach for the city to outsource green management to individual residents (URGETEAM 2004). The activity and the gardening areas are visually separated by hedges and some by brick walls. These natural separation elements were implemented so as to minimize potential conflicts, e.g. between children playing in the playground areas and local residents walking their dogs.

The structure of the former railway site was used to increase the aesthetic quality of the area by keeping the overground pipeline or using recycled materials and parts of the former rails as wall constructions (URGE-TEAM 2004). Along the main routes, sealed tracks for cycling and walking along the park and some intersections were implemented so that residents could avoid the streets as much as possible to get from one place to another within the district. Open entrances from all city directions combined with rails without barriers enable easy access for all user groups. The open design of the main area allows wind circulation and a wide view to the city centre (Fig. 2c,d, and g). The first sections of the park were opened for public use in 2001, and the final section in 2004 (Costa and Mathey 2007; URGE-TEAM 2004).

The site visits clearly showed that today, the Lene-Voigt Park is a multifunctional recreational park with a diverse range of use opportunities. The large recreational lawn areas in the main section of the park are often used by a wide range of population groups including kindergarten groups, students and others meeting during the day. The activity areas containing several playgrounds and sports fields for playing beachvolleyball, soccer, basketball and table tennis are regularly used (weather conditions permitting). Following the requests of children from the youth camp in the co-design phase as indicated in one of the interviews with a representative of academia who was involved in the participation process, the playgrounds were equipped with big slides 
a)

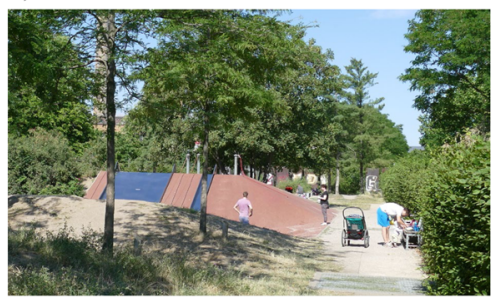

c)

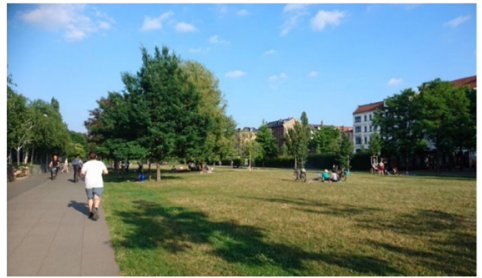

e)

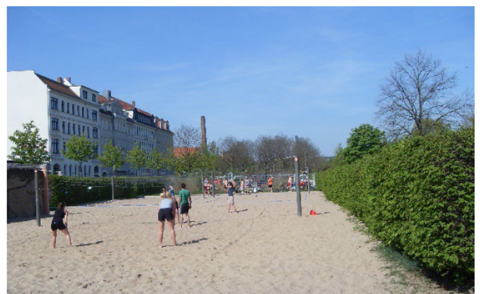

g)

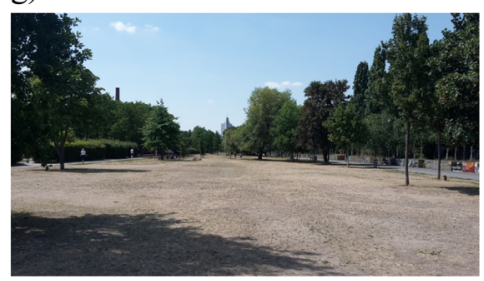

i)

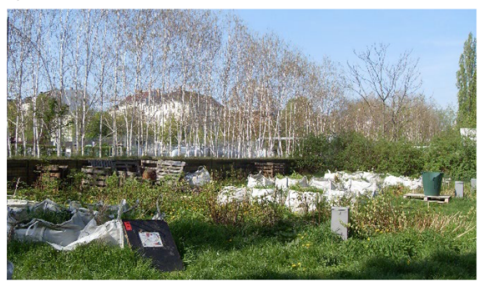

b)

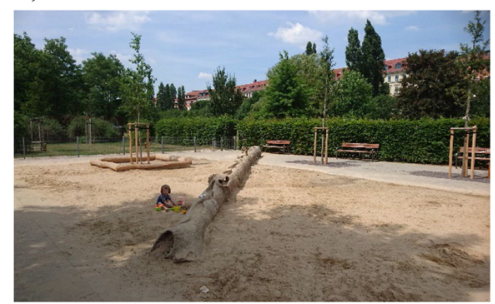

d)

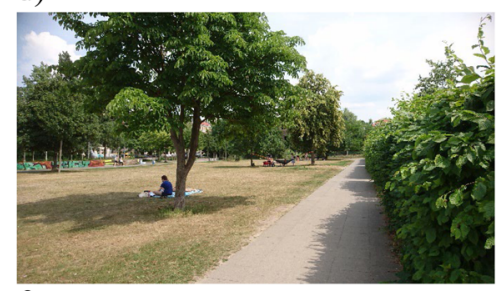

f)

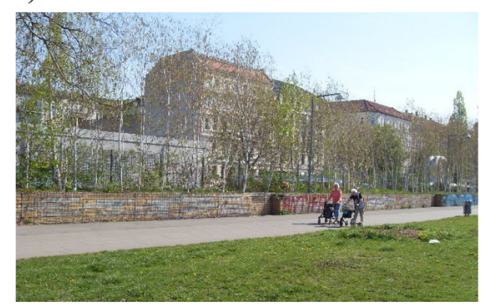

h)

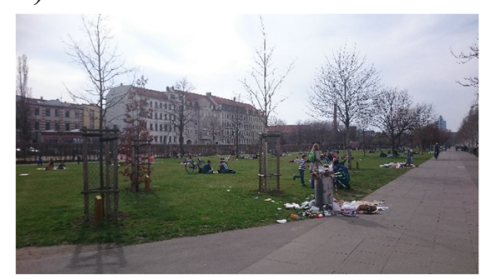

j)

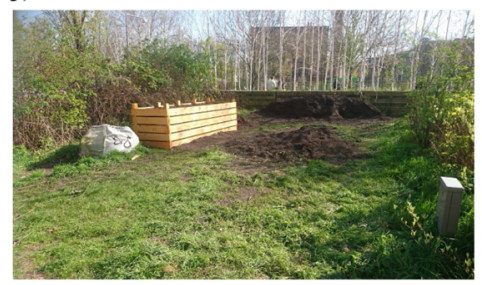

Fig. 2 Expressions from Lene-Voigt Park - a former railway brownfield in the city of Leipzig. Legend: use. a and $\mathbf{b}$ Children using the park with play areas in partially separated areas. For the children slides see also https://www.leipzig.de/detailansicht-adresse/spielplatz-lene-voigt-park-rutschplatz/. c and $\mathbf{d}$ main area of the park for multi-purpose. e Beach-volley ball field. $\mathbf{f}$ Elderly people using the sealed parts without barriers. $\mathbf{g}$ Lawn are under heat stress during summer 2018. h Waste problem in the park. i Neglected lots for urban gardening in 2018. j New urban gardening activities and experiments in April 2019. All pictures taken by GreenEquityHEALTH group members (www.greenequityhealth.hu-berlin.de)

designed in a way that children can slide next to each other (Fig. 2a). Kindergarten groups and families mainly use the playgrounds, whereas mostly teenagers, youths, young people and students regularly play on the sports fields (Fig. 2b). Groups of all ages and from different cultures frequently use the lawn areas for BBQ's, socialising, 
playing, etc. Elderly people and disabled residents meet up in the spaces (Fig. 2f). Furthermore, some areas are also used for arts and cultural events.

\section{Lene-Voigt Park challenges today}

Although the Lene-Voigt Park can be regarded as a success story in providing many use opportunities in particular for recreational and socialising activities (URGE-TEAM 2004), several challenges have also arisen. These challenges were identified through both, the semi-structured interviews and the site visits during 2018 and 2019.

First, not all of the initial ideas framed during the co-design and co-creation process worked out in the way that they had initially been planned. One of those ideas was the creation of an urban gardening community and the use of the gardening lots on the site by individual local residents or community groups from the neighborhood. City authorities regarded maintaining parts of urban green by local residents as a new and innovative management strategy. Initial attempts of gardening activities took place but did not last over the years (see Fig. 2i). Some of the lots are partly used but were not well-maintained, whereas others have been left abandoned as identified through the site visits. Interviews with local authorities from city's urban planning departments and some of the neighbourhood groups indicated that physical barriers such as the streets between the residential area and the park and visual barriers such as the brick wall and the birch lane separating the lots from the main part of the park together with no direct access between residential buildings and the gardens, combined with the fear of potential vandalism that happened in some cases over recent years, may represent some of the main barriers preventing long-term gardening activities here. Safety issues were mentioned during the interviews such as the fact that the lots cannot be locked and are partly hidden by the hedges and brick walls. This obviously increased the potential of vandalism and mistrust in the area. Further, community gardening certainly requires some place attachment with longer term commitments from the local population (Exner and Schützenberger 2018). In the eastern part of the inner city where the Lene-Voigt Park is located, high vacancy rates existed at the time when the park was established. Those vacancy rates have decreased due to renovation and restructuring programmes of the local housing stock (as part of the STEP W + S) and rents have increased over the last two decades, all resulting in high in- and outmigration rates. The safety concerns combined with less developed long-term connectedness to the place may have been the main obstacles in creating an established urban gardening community in the Lene-Voigt Park. Nevertheless, the initial project may be regarded as experimental arena for both the local communities and the city authorities where lessons learned may work better today as site visits showed that very recent attempts starting in 2019 tried to revive the use of at least some of the gardening lots, by including local NGOs (non-governmental organisations such as the BUND - Friends of the Earth Germany) in the management (Fig. 2j).

Another challenge for the Lene-Voigt Park is the partly overused lawn areas combined with severe environmental conditions as several site visits during several seasons of the year have shown. As Leipzig has grown over the last two decades, continuous population growth has also lead to a massive and frequent use of the city's urban green spaces which has in particular threatened the condition of the lawn areas. As the LeneVoigt Park is extensively used as a meeting space for large groups in the afternoon and 
evening hours, in some parts the vegetation of the lawn areas has not recovered from overuse, in particular after the extreme drought and heat period from the summer in 2018 (see Fig. 2g). The city departments are aware of this and are trying to revive the lawn areas with development measures but still these areas appear as bare soil in several areas.

Finally, the city has to deal with occasional vandalism such as graffiti and the demolition of benches and massive waste created by large user groups that meet for BBQs during the evening hours. The problem of large-scale waste collection presents a challenge for the city of Leipzig (Fig. 2h). Local community initiatives together with the NGO BUND occasionally organise joint walks through the Lene-Voigt Park to collect waste (Leipziger Volkszeitung - LVZ 2019). These informal walks are also used to exchange in the community and with park visitors about potential strategies to maintain the park clean. Another issue that is often mentioned relates to the missing public toilets. The lack of toilets is another threat to the park and even more important for families with children.

\section{Discussion}

The co-creation process involving a multitude of actors proved mainly successful in the case of the Lene-Voigt Park in Leipzig. Similar success stories have happened in other large cities that have regrown and provide brownfield sites for potential urban regeneration projects. Examples include the Gleisdreieck in Berlin (Hansen et al. 2015), or similar areas in London and Toronto as presented earlier on in the paper. However, intensive participatory processes involving a diversity of actors and stakeholder groups in transdisciplinary processes are still rarely adopted (Raymond et al. 2017a). This may be a result from path dependencies in traditional planning implementation schemes that follow top-down approaches even though success cases such as the Lene-Voigt Park or others have shown that they work best when a variety of actors are involved and transparent strategies for information flow and communication is used throughout the whole process (Frantzeskaki and Kabisch 2016a; Frantzeskaki et al. 2017; Mancebo 2015). Communicating the multiple benefits that residents would gain from brownfield transformation processes as well as understanding and adapting to their needs, desires or even financial constraints or limitations should become a transversal activity throughout an entire project period (Raymond et al. 2017b). In fact, research has shown that communication works best when realized through a series of both parallel and overlapping top-down and bottom-up processes. This could include new ways of collaboration including private-public partnerships, social innovation e.g. through arts involvement or community garden responsibilities, or, dialogue platforms for different actors - including children to innovate the participation and communication process (Nordström and Wales 2019). In particular, collaborative and imaginative approaches of communication and participation with visualisations, vision building and permanent feedback will increase support and acceptance (Raymond et al. 2017a; Frantzeskaki and Kabisch 2016a; Jones and Somper 2014). For example, Glass et al. (Glaas et al. 2018) showed that addressing urban transformation tasks may be stimulated by tailored visualisation tools that support the creation of shared system awareness and the coproduction of knowledge between scientists and urban planners and decision makers applied in three Swedish cities. 
Without the inclusion of the local community there is still a risk that the creation of a new green space may not provide a real service to its local residents, because they simple do not start using them as was the case with Seint Saint Denis (Mancebo 2014).

As the redevelopment of a former railway brownfield into the Lene-Voigt Park has shown, challenges still remain that include unforeseen processes such as an overuse of the area, the waste problem or the fact that practical usage constraints prevail, as in the case of urban gardening. Community gardening in cities is often associated with place attachment and self-responsibility which are both emerging since some years at the Lene-Voigt Park and in the local neighbourhood but may not have been developed sufficiently at the time of the co-creation process (Exner and Schützenberger 2018). The increase of system awareness here including knowledge on path-dependencies and potential future urban developments (including demographic changes and residential developments) on different temporal and spatial scales may however help to increase urban transformative capacity (see Wolfram et al. 2019). In particular the consideration of the temporal scale may be taken as social learning opportunity to be considered in future brownfield transformations projects.

\section{Conclusion}

This paper has drawn on the case of a co-creation process for transforming a former railway site into a multifunctional public park to suggest new perspectives for sustainable urban regeneration strategies. The main orientations that derive from the case of the Lene-Voigt Park in Leipzig are therefore:

$>$ The active involvement of a diversity of actors including local residents at different ages and from different cultural backgrounds, community groups, planners, decision makers and researchers in the planning and implementation process is decisive for a successful transformation project.

$>$ The design should be based on transparent, open and intensive participation processes in which community groups are enabled and encouraged to discuss and argue for their needs and desires together with city planners, designers and supported by researchers. This allows creating a multitude of opportunities for several recreational and socialising activities translated into many differently designed park elements including playground, sports facilities and recreational areas. Both, the intensive co-creation process and the provision of the diverse opportunities support a broad acceptance and use.

$>$ Some barriers to use the opportunities such as safety concerns may exist that can hinder a complete transformation of an area. This is linked to the particularities of the local context in a temporal scale dimension. Past and future socio-economic conditions and the demographic development of an area should therefore be considered and lessons learned from a current case may help to improve future transformation projects.

$>$ Related to the dimension of time, demographic development and environmental context is the need to anticipate potential changes that may require an adaptation of the maintenance concepts and implementation of infrastructure such as waste bins and toilets.

In conclusion, adaptive urban planning that includes evaluation and regular monitoring of urban transformation projects, continuous co-creation in public discussion arenas (Raymond et al. 2017b) and, finally, flexible management strategies will help cities to successfully implement sustainable solutions and react comprehensively to emerging challenges. 


\section{Acknowledgements}

I would like to thank two anonymous reviewers for their helpful commentsto an earlier version of the manuscript. This work was carried out within the research project 'Environmental-health Interactions in Cities (GreenEquityHEALTH) Challenges for Human Well-being under Global Changes' (2017 to 2022; www.greenequityhealth.hu-berlin.de) funded by the German Federal Ministry of Education and Research (BMBF), funding code: 01LN1705A.

\section{Author's contributions}

NK is the single author of the manuscript. She has designed and written the manuscript. The author read and approved the final manuscript.

\section{Authors' information}

Nadja Kabisch (nadja.kabisch@geo.hu-berlin.de) is a social geographer and land-use scientist working on the impacts of urban green space on public health and environmental justice in cities and on cultural urban ecosystem services at the Humboldt-Universität zu Berlin and the Helmholtz Centre for Environmental Research-UFZ, in Leipzig, Germany. She is leading the Department Urban Ecosystems, Health and Environmental Justice at the Humboldt-Universität zu Berlin.

\section{Funding}

This work was carried out within the research project 'Environmental-health Interactions in Cities (GreenEquityHEALTH) - Challenges for Human Well-being under Global Changes' (2017 to 2022; www.greenequityhealth.hu-berlin.de) funded by the German Federal Ministry of Education and Research (BMBF), funding code: 01LN1705A.

\section{Availability of data and materials}

Data sharing not applicable to this article as no datasets were generated or analysed during the current study.

\section{Competing interests}

The author declares that she has no competing interests.

Received: 9 January 2019 Accepted: 1 August 2019

Published online: 18 November 2019

\section{References}

Balaban O, Puppim de Oliveira JA. Understanding the links between urban regeneration and climate-friendly urban development: lessons from two case studies in Japan. Local Environ. 2014;19:868-90 https://doi.org/10.1080/13549839. 2013.798634

Banzhaf E, Kollai H, Kindler A. Mapping urban grey and green structures for liveable cities using a 3D enhanced OBIA approach and vital statistics. Geocarto Int 0:1-18. 2018. https://doi.org/10.1080/10106049.2018.1524514.

Bowler DE, Buyung-Ali L, Knight TM, Pullin AS. Urban greening to cool towns and cities: a systematic review of the empirical evidence. Landsc Urban Plan. 2010;97:147-55 https://doi.org/10.1016/j.landurbplan.2010.05.006.

City of Leipzig. Neue Freiräume im Leipziger Osten. 2005.

City of Leipzig. Anlage 2 SEKO Leizpig - B13 Fachteil Brachen. 2015a.

City of Leipzig. Population prognosis 2016. Leipzig; 2015b.

City of Leipzig. Leipzig - Stadtgebiet nach Nutzungsarten. 2018a. https://statistik.leipzig.de/statcity/table.aspx?cat=1\&rub=2.

City of Leipzig. Lene-Voigt Park. 2018b. https://www.leipzig.de/freizeit-kultur-und-tourismus/parks-waelder-und-friedhoefe/ parks-und-gruenanlagen/lene-voigt-park/.

Connop S, Vandergert P, Eisenberg B, et al. Renaturing cities using a regionally-focused biodiversity-led multifunctional benefits approach to urban green infrastructure. Environ Sci Pol. 2016;62:99-111 https://doi.org/10.1016/j.envsci. 2016.01.013.

Costa CS, Mathey J. Grünflächenentwicklung als Beitrag zur Stadterneuerung. Ein interdisziplinärer Ansatz zur Grünflächeneinschätzung. In: Jahrbuch Stadterneuerung 2006/2007 - Stadterneuerung und Landschaft. Berlin: Universitätsverlag der TU Berlin; 2007. p. 418.

De Sousa CA. Turning brownfields into green space in the City of Toronto. Landsc Urban Plan. 2003;62:181-98.

Dzhambov AM, Dimitrova DD. Green spaces and environmental noise perception. Urban For Urban Green. 2015;14:1000-8 https://doi.org/10.1016/j.ufug.2015.09.006.

European Environment Agency. Unequal exposure and unequal impacts: social vulnerability to air pollution, noise and extreme temperatures in Europe. 2018.

Exner A, Schützenberger I. Creative natures. Community gardening, social class and city development in Vienna. Geoforum. 2018:92:181-95 https://doi.org/10.1016/j.geoforum.2018.04.011.

Fischer LK, Honold J, Botzat A, et al. Recreational ecosystem services in European cities: sociocultural and geographical contexts matter for park use. Ecosyst Serv. 2018:1-13 https://doi.org/10.1016/j.ecoser.2018.01.015.

Frantzeskaki N, Borgstrom S, Gorissen L, et al. Nature-based solutions accelerating urban sustainability transitions in cities: lessons from Dresden, Genk and Stockholm cities. In: Kabisch N, Korn H, Stadler J, Bonn A (eds) Nature-based solutions to climate change adaptation in urban areas linkages between science, Policy and Practice. Cham: Springer; 2017. pp 65-90.

Frantzeskaki N, Kabisch N. Designing a knowledge co-production operating space for urban environmental governance-lessons from Rotterdam, Netherlands and Berlin, Germany. Environ Sci Pol. 2016a;62:90-8. https://doi.org/ 10.1016/j.envsci.2016.01.010

Frantzeskaki N, Kabisch N Setting a knowledge co-production operating space for urban environmental governance lessons from Rotterdam, Netherlands and Berlin, Germany. Environ Sci Policy (2016b).

Glaas E, Hjerpe M, Storbjörk S, et al. Developing transformative capacity through systematic assessments and visualization of urban climate transitions. Ambio. 2018:515-28 https://doi.org/10.1007/s13280-018-1109-9. 
Hansen R, Buizer M, Rall E, et al. Report on case Study City portraits appendix - GREEN SURGE study on urban green infrastructure planning and governance in 20 European case studies. 2015.

Hartig T, Mitchell R, de Vries S, Frumkin H. Nature and health. Annu Rev Public Health. 2014;35:207-28 https://doi.org/10. 1146/annurev-publhealth-032013-182443.

Intergovernmental Panel on Climate Change. Global warming of $1.5^{\circ} \mathrm{C} .2018$

Jones S, Somper C. The role of green infrastructure in climate change adaptation in London. Geogr J. 2014;180:191-6.

Kabisch N. Ecosystem service implementation and governance challenges in urban green space planning - the case of Berlin, Germany. Land Use Policy. 2015;42:557-67 https://doi.org/10.1016/j.landusepol.2014.09.005

Kabisch N. GreenEquityHEALTH - Project Factsheet, vol. 1; 2018. p. 4. https://www.geographie.hu-berlin.de/de/Members/ Kabisch_Nadja/greenequityhealth-factsheet-v06-final-web.pdf.

Kabisch N, Haase D. Diversifying European agglomerations: evidence of urban population trends for the 21st century. Popul Space Place. 2011;17. https://doi.org/10.1002/psp.600.

Kabisch N, Korn H, Stadler J, Bonn A. Nature-based solutions to climate change adaptation in urban areas: Springer International Publishing; 2017a.

Kabisch N, Qureshi S, Haase D. Human-environment interactions in urban green spaces - a systematic review of contemporary issues and prospects for future research. Environ Impact Assess Rev. 2015;50 https://doi.org/10.1016/j.eiar. 2014.08.007.

Kabisch N, van den Bosch M, Lafortezza R. The health benefits of nature-based solutions to urbanization challenges for children and the elderly - a systematic review. Environ Res. 2017b;159:362-73 https://doi.org/10.1016/j.envres.2017.08.004.

Leipziger Volkszeitung - LVZ. BUND sammelt mit Bürgern Müll im Lene-Voigt-Park. Leipziger Volkszeitung. 2019.

Mancebo F. Combining sustainability and social justice in the Paris metropolitan region. In: Isenhour C, McDonogh G, Checker M, editors. Sustainability in the Global City Myth and Practice: Cambridge University Press; 2014. p. 263-84.

Mancebo F. The nurtured golem: a Nantes neighborhood transforms environmental bad into good; 2015. https://www. thenatureofcities.com/2015/09/27/the-nurtured-golem-a-nantes-neighborhood-transforms-environmental-bad-into-good/.

McCormack GR, Rock M, Swanson K, et al. Physical activity patterns in urban neighbourhood parks: insights from a multiple case study. BMC Public Health. 2014;14:962 https://doi.org/10.1186/1471-2458-14-962.

McCormack GR, Rock M, Toohey AM, Hignell D. Characteristics of urban parks associated with park use and physical activity: a review of qualitative research. Health Place. 2010;16:712-26 https://doi.org/10.1016/j.healthplace.2010.03.003.

Nordström M, Wales M. Enhancing urban transformative capacity through children's participation in planning. Ambio. 2019: 507-14 https://doi.org/10.1007/s13280-019-01146-5.

Nowak DJ, Crane DE, Stevens JC. Air pollution removal by urban trees and shrubs in the United States. Urban For Urban Green. 2006:4:115-23.

Rall EL, Haase D. Creative intervention in a dynamic city: a sustainability assessment of an interim use strategy for brownfields in Leipzig. Germany Landsc Urban Plan. 2011;100. https://doi.org/10.1016/j.landurbplan.2010.12.004.

Raymond CM, Frantzeskaki N, Kabisch N, et al. A framework for assessing and implementing the co-benefits of nature-based solutions in urban areas. Environ Sci Pol. 2017a;77:15-24 https://doi.org/10.1016/j.envsci.2017.07.008.

Raymond CM, Frantzeskaki N, Kabisch N, et al. A framework for assessing and implementing the co-bene fi ts of nature-based solutions in urban areas. Environ Sci Pol. 2017b;77:15-24 https://doi.org/10.1016/j.envsci.2017.07.008.

United Nations - Department of Economic and Social Affairs (2018) World Urbanization Prospects - The 2018 Revision Key Facts.

URGE-TEAM (2004) Making Greener Cities - A Practical Guide.

Wolch J, Jerrett M, Reynolds K, et al. Childhood obesity and proximity to urban parks and recreational resources: a longitudinal cohort study. Health Place. 2011;17:207-14 https://doi.org/10.1016/j.healthplace.2010.10.001.

Wolff M, Haase A, Haase D, Kabisch N. The impact of urban regrowth on the built environment. Urban Stud. 2017;54:2683700 https://doi.org/10.1177/0042098016658231.

Wolfram M, Borgström S, Farrelly M. Urban transformative capacity: from concept to practice. Ambio. 2019:437-48. https:// doi.org/10.1007/s13280-019-01169-y.

Ziter CD, Pedersen EJ, Kucharik CJ, Turner MG. Scale-dependent interactions between tree canopy cover and impervious surfaces reduce daytime urban heat during summer. Proc Natl Acad Sci. 2019;201817561. https://doi.org/10.1073/pnas. 1817561116.

\section{Publisher's Note}

Springer Nature remains neutral with regard to jurisdictional claims in published maps and institutional affiliations.

\section{Ready to submit your research? Choose BMC and benefit from}

- fast, convenient online submission

- thorough peer review by experienced researchers in your field

- rapid publication on acceptance

- support for research data, including large and complex data types

- gold Open Access which fosters wider collaboration and increased citations

- maximum visibility for your research: over $100 \mathrm{M}$ website views per year

At BMC, research is always in progress.

Learn more biomedcentral.com/submissions 